\title{
Configurações
}

Revista de sociologia

\section{Dimensões e impactos da ficção científica forense: que efeitos CSI?}

Dimensions and impacts of forensic science fiction: What CSI effects?

Dimensions et impacts de la science-fiction sur la médicine légale : quels sont les effets de la CSI?

Filipe Santos

\section{(2) OpenEdition}

\section{Journals}

\section{Edição electrónica}

URL: http://journals.openedition.org/configuracoes/795

DOI: 10.4000/configuracoes.795

ISSN: 2182-7419

\section{Editora}

Centro de Investigação em Ciências Sociais

\section{Edição impressa}

Data de publição: 5 Fevereiro 2011

Paginação: 109-124

ISSN: 1646-5075

\section{Refêrencia eletrónica}

Filipe Santos, « Dimensões e impactos da ficção científica forense: que efeitos CSI? », Configurações

[Online], 8 | 2011, posto online no dia 21 fevereiro 2013, consultado o 19 abril 2019. URL : http:// journals.openedition.org/configuracoes/795 ; DOI : 10.4000/configuracoes.795

Este documento foi criado de forma automática no dia 19 Abril 2019.

(c) CICS 


\title{
Dimensões e impactos da ficção científica forense: que efeitos CSI?
}

\author{
Dimensions and impacts of forensic science fiction: What CSI effects? \\ Dimensions et impacts de la science-fiction sur la médicine légale : quels sont les \\ effets de la CSI?
}

Filipe Santos

\section{Introdução: 0 CSI e a ficção científica forense}

1 As séries televisivas, e os média em geral, reflectem frequentemente mudanças societais com impactos ao nível das percepções públicas da lei e da ordem, do combate ao crime e das potenciais ameaças (Altheide, 1992; Reiner, 2002). Na contemporaneidade, a série de ficção televisiva Crime Scene Investigation (CSI) é talvez o precursor e tornou-se quase sinónimo de um novo género de ficção televisiva policial ${ }^{1}$.

2 Este artigo tem por objectivo facultar uma breve revisão da bibliografia em torno do chamado "Efeito CSI", confrontando várias abordagens académicas e científicas a um fenómeno que vem suscitando relatos controversos nos média norte-americanos, ao mesmo tempo que pretende lançar questões prospectivas para futuras pesquisas no contexto português. $O$ ponto de partida situa-se na caracterização de um imaginário que a difusão de séries televisivas vem impregnando na cultura popular e que apresenta um certo potencial homogeneizante em virtude do carácter transcultural das narrativas e personagens associadas aos dramas criminais. Na senda de estudos anteriores (vejam-se, por exemplo, Machado et al., 2008; Machado e Santos, 2011; Santos, 2005), algumas conclusões apontam no sentido da emergência de uma retórica laudatória da ciência e da tecnologia ao serviço da justiça portuguesa como panaceia para as suas enfermidades.

o crime e o combate ao crime têm sido um dos principais filões temáticos da produção ficcional desde finais do século XIX até aos dias de hoje. Se personagens como Sherlock Holmes ou Hercule Poirot se destacaram na literatura policial pelo seu poder de observação e de dedução, a ficção televisiva policial, predominantemente norte-americana, teve 
períodos no pós-II Guerra Mundial em que o combate ao crime era levado a cabo por "heróis" solitários com tendência para contornar as regras e usar mais os músculos do que o cérebro, em séries como Starsky and Hutch ou Miami Vice (Hans e Dee, 1991: 139; Cavender e Deutsch, 2007).

4 A popularidade da série CSI tem proporcionado, ao longo das várias temporadas e desde a sua estreia em 2000, nos EUA, relevantes sucessos de audiências (Cavender e Deutsch, 2007: 67; Gever, 2005: 446). Também em Portugal, onde a série CSI e os seus spin-offs (CSI: Miami e CSI: New York) são exibidas na SIC e no canal de cabo AXN, tem sido uma aposta consistente e com bons resultados por parte destes canais ${ }^{2}$.

a emergência de novos modelos de policiamento e novas formas de combate ao crime. Na série CSI, mas também noutras séries do mesmo género, os actores representam modelos de agentes da lei algo diferentes do que é habitual nos dramas criminais. $O$ facto de as personagens na série circularem frequentemente entre o laboratório e as cenas de crime, realizando interrogatórios e promovendo detenções, implica uma certa elisão de hierarquias de competência e saberes no panorama da investigação criminal e combate ao crime.

6 A espécie de híbrido polícia/cientista propagada na série CSI contribui para a disseminação na cultura popular de um imaginário onde a investigação criminal, investida do poder da ciência, se apresenta sem as ambiguidades e incertezas do mundo real. Isto é, ao introduzir um aparente realismo científico no tradicional género televisivo acerca do crime, séries como CSI criam aquilo que autores como Sarah Deutsch e Gray Cavender (2008: 34-5) designam como uma "teia de facticidade forense" que contribui para a circulação e validação de significados culturais acerca da investigação criminal. Porém, apesar do aparente realismo e exequibilidade das técnicas forenses representadas, o grau de precisão, fiabilidade, rapidez e disponibilidade é em grande parte distorcido e exagerado (Patry et al., 2008). Tanto mais que as narrativas ficcionais deste género muito raramente fornecem representações acerca das contendas adversariais nos tribunais, dos conflitos acerca da admissibilidade das provas ou dos testemunhos apresentados pelos peritos (Hans e Dee, 1991), deste modo propalando um imaginário onde a materialidade da prova se apresenta como verdade absoluta (Kruse, 2010: 80).

7 Deste modo, as representações da polícia e da investigação criminal que circulam na série CSI configuram e acentuam as dimensões de neutralidade e objectividade associadas à tecnologia em geral, mas em particular às ferramentas que são frequentemente usadas nesta série de ficção e que se articulam para revelar uma solução para o crime. Não é raro observar as personagens recorrerem a uma multiplicidade de bases de dados e ferramentas tecnológicas que fornecem informações instantâneas que muitas vezes se revelam fulcrais - desde bases de dados de produtos manufacturados, impressões digitais, registos criminais ou perfis de DNA, até câmaras de videovigilância, registos de comunicações telefónicas, dados bancários, etc.

8 A disseminação deste imaginário, no qual a ubiquidade da informação parece ser uma constante e unívocas as respostas obtidas, constrói narrativas populares que tendem a tornar-se hegemónicas num contexto em que "o crime é tipicamente assumido como o problema e as ferramentas para combater o crime são a resposta" (Prainsack e Toom, 2010: 1129).

9 É provável, então, que as audiências, mas também o público em geral, possam construir a partir destas narrativas um imaginário da ciência forense, das tecnologias de 
identificação por perfis de DNA e dos próprios agentes de investigação, que, embora assente numa aparente verosimilhança relativamente a algumas técnicas, ignora as contingências das suas aplicações no mundo real e nos tribunais ou os contextos actuais de produção (Costa, 2003; Pratt et al., 2006; Robbers, 2008).

Em que medida podem programas televisivos influenciar as audiências e o público em geral? Os contributos teóricos neste âmbito são provenientes dos estudos dos média e da psicologia social, designadamente, derivados da cultivation theory que, na sua versão original, assinalava correspondências e relações entre o consumo televisivo e as crenças e percepções dos respondentes, assinalando uma tendência para a reprodução discursiva das imagens do mundo e da vida que são veiculadas pela televisão, particularmente em temas relacionados com a violência, o crime e as forças da lei (Gerbner e Gross, 1976). Embora a maioria da informação acerca de assuntos públicos, particularmente aqueles que estão mais afastados da experiência quotidiana, seja produzida e veiculada pelos média, não se pode tomar as audiências como receptores passivos (Guibentif et al., 2002; Sacco, 1995). Contudo, na ausência de experiências em primeira mão, estudos da área da psicologia social apontam para a intervenção de efeitos de memórias implícitas (priming) ${ }^{3}$ na formação de opiniões (Brewer e Ley, 2010: 97). Admite-se, então, que os indivíduos sem experiência directa do funcionamento real e concreto do mundo da investigação criminal e da ciência forense recorram a imagens e noções adquiridas por via das suas representações mediáticas, em processos mentais análogos à esterotipificação para lidar com a complexidade inerente à criminalidade no mundo real.

O desenvolvimento deste artigo é estruturado em três parte principais. No seguimento de uma sucinta explanação acerca da origem do chamado "Efeito CSI", é apresentada uma proposta de tipologia com a intenção de caracterizar a diversidade de pressupostos e impactos, alegadamente resultantes da série CSI. A segunda seç̧ão aborda os diversos estudos empíricos levados a cabo com o objectivo geral de averiguar os eventuais efeitos da série CSI sobre os processos de tomada de decisão em contextos judiciais simulados, nomeadamente, procurando avaliar a hipótese de que os veredictos dos membros de um júri são afectados pelo seu grau de contacto com séries de ficção científica forense. Por último, a partir de estudos que procuram averiguar os impactos junto de outras populações relevantes, tais como agentes da polícia ou reclusos, são ponderados potenciais efeitos e impactos no contexto português.

\section{0 que é o "Efeito CSI"?}

O termo "Efeito CSI" surgiu nos média norte-americanos em 2002, pouco tempo após a estreia da série nos Estados Unidos da América (Cole e Dioso-Villa, 2007: 443), tendo, desde então, suscitado preocupações e pesquisas acerca da sua existência ${ }^{4}$. No contexto de um sistema de justiça criminal do tipo adversarial, em que o papel do juiz é frequentemente o de um árbitro passivo ao qual compete definir as regras do julgamento e a admissibilidade das provas apresentadas, cabe aos representantes das partes envolvidas argumentar acerca da validade e do significado jurídico das provas admitidas a julgamento. Entende-se que o papel dos jurados é o de aferir e adjudicar, quase num sentido binário (verdadeiro/falso, inocente/culpado), a matéria de facto trazida perante o tribunal (Zalman, 2008: 82). Assinale-se que, nos EUA, os julgamentos por júri são bastante frequentes na área criminal. 
13 Foi então, com relativo alarme e preocupação, que os média deram destaque à possibilidade de um novo fenómeno na justiça criminal. Os relatos acerca do chamado "Efeito CSI" citam advogados de defesa, procuradores e juízes que argumentam que, por influência das imagens ficcionais da ciência forense e do funcionamento da investigação criminal, os jurados têm expressado expectativas e exigências incongruentes com a situação real do sistema de justiça criminal. Os relatos apontam para um potencial efeito relacionado com as expectativas elevadas dos jurados, passível de produzir consequências paradoxais, dependendo do observador. Por um lado, advogados de defesa dizem-se prejudicados pelo excessivo valor depositado na prova científica por parte dos jurados e, por outro lado, procuradores encarregues da acusação observam que é mais difícil obter uma condenação quando a prova científica é irrelevante ou ausente (Willing, 2004).

Conclui-se, então, que o pressuposto principal do "Efeito CSI" estabelece uma relação entre a exposição e consumo de ficção televisiva em que a ciência forense é de certa forma representada como infalível e as perceções e avaliações de prova científica no mundo real (Podlas, 2006: 437). As preocupações associadas à possibilidade de os veredictos estarem a ser contaminados por expectativas exageradas relativamente à prova científica levaram ao estudo académico do "Efeito CSI". No entanto, e tendo em mente o contexto português, afigura-se redutor o enfoque no âmbito judicial e dos julgamentos por júri. Assim, a próxima secção incidirá sobre outras possíveis dimensões e actores do chamado "Efeito CSI".

\section{Uma proposta de tipologia}

Antes de fazer referência a estudos empíricos, importa considerar uma tipologia do "Efeito CSI" elaborada por Simon Cole e Rachel Dioso-Villa (2007). Os autores problematizam o "Efeito CSI" de um modo que lembra o algo controverso "teorema" de Thomas 5 , isto é, mesmo que para muitos actores legais e académicos o "Efeito CSI" possa não passar de um efeito mediático de pânico infundado, os média, particularmente nos EUA, referem-se a ele como se fosse real e concreto. A mesma ideia é sublinhada por Tom Tyler (2006: 1055) quando diz que, apesar da ausência de evidência empírica da existência de um "Efeito CSI", não é novidade que os jurados em casos reais são afectados nas suas representações e percepções pelo imaginário do mundo legal veiculado pelos média. Ainda que tal não confirme a sua existência, poderá constituir indício de plausibilidade.

A gama tipológica das diversas variantes que surgem nas narrativas mediáticas acerca do "Efeito CSI" sugerem impactos sociais mais diversificados que podem extravasar o domínio judicial. Cole e Dioso-Villa (2007) tipificam seis variantes que passamos a explanar. A variante "acusação forte" (strong prosecutor) é considerada a mais corrente nas narrativas mediáticas e postula que os acusados são indevidamente ilibados por causa da ausência ou irrelevância de prova científica. Trata-se de um efeito "forte", na medida em que se pressupõe que, na ausência de ficção televisiva do género CSI, os réus seriam condenados, pois os jurados não colocariam o seu critério de dúvida razoável num patamar somente atingível pela "certeza absoluta" conferida pela derradeira prova científica, embora pudesse existir outro tipo de provas. Seria esta, eventualmente, a variante mais preocupante e que justificaria algum "pânico", uma vez que pressupõe que a eficácia do sistema de justiça é posta em causa por crenças e expectativas exageradas. 
17 Na variante que descreve a "acusação fraca" (weak prosecutor's effect), há uma espécie de antecipação da variante anterior por parte da acusação. Isto é, antevendo eventuais expectativas elevadas por parte dos jurados, o procurador informa o júri durante a fase de voir dire ${ }^{6}$, tentando explicar a ausência ou falta de conclusividade das provas e eliminando os candidatos a jurado que acredite serem susceptíveis a influências do CSI. Segundo Cole e Dioso-Villa (2007), esta variante do efeito incide mais sobre os próprios procuradores do que sobre os jurados, não afectando potencialmente o resultado final de um julgamento. Na perspectiva da "defesa" ou do acusado (defendant's effect), a variante do "Efeito CSI" será no sentido de considerar que o júri sobrevaloriza o testemunho de peritos forenses devido ao imaginário veiculado nas séries televisivas. A imagem de empenho, eficiência e quase infalibilidade ajuda a construir uma sólida imagem de credibilidade dos peritos e das tecnologias ao seu dispor, assim como de qualquer testemunho que estes prestem no âmbito de um qualquer caso real. Tyler (2006) designa esta variante como o "reverso do Efeito CSI" (geralmente pensada como a variante da "acusação forte"), referindo que esta é plausível na presença de factores emocionais por parte dos jurados. Por exemplo, pode suceder que os jurados emitam veredictos mais influenciados por uma necessidade psicológica de punir indivíduos acusados de crimes terríveis, de modo a restaurar o equilíbrio moral da comunidade, do que por uma análise racional das provas e argumentos existentes. Este efeito psicológico poderá, assim, levar à sobrevalorização das provas, favorecendo a acusação (Tyler, 2006: 1050).

O "efeito do produtor" (producer's effect), como é designado por Cole e Dioso-Villa (2007), sustenta que o visionamento de ficção forense acarreta benefícios ao nível educacional, tornando o público mais capaz de interpretar e avaliar a prova científica caso seja necessário prestar testemunho ou participar num júri.

20 Na chamada "versão do professor" (professor's version), há uma dimensão do "Efeito CSI" que leva a um maior interesse e procura de cursos de formação na área da ciência forense e criminologia por parte de indivíduos seduzidos pelo imaginário veiculado por séries como CSI. É possível que esta última variante se tenha já manifestado em Portugal7.

Por fim, a última variante é designada por "versão da polícia” (police chief's version) (Cole e Dioso-Villa, 2007: 435). Aqui também são valorizados os aspectos educacionais da série CSI , embora o "público" e as finalidades das aprendizagens adquiridas por via do visionamento da série sejam bastante distintos das propostas pela "versão do produtor". Alegadamente, a série funciona como veículo educacional para os criminosos ou potenciais criminosos, alertando-os para os dispositivos de detecção e vigilância. É sugerido que a série ensina técnicas e avisa estes públicos particulares para as vantagens de eliminar pistas dos locais de crime, tornando o crime e os criminosos mais sofisticados.

Poderão, assim, aprender a importância do uso de luvas, gorros e até plásticos para cobrir os pés, mas também a "limpar" as cenas de crime, por exemplo, eliminando vestígios de sangue com lixívia.

Com efeito, as variantes acima descritas prefiguram dimensões marcantes que não deverão ser desprezadas se se pretende ponderar os impactos sociais da série CSI. Todavia, os estudos empíricos realizados tendem a problematizar os eventuais efeitos sobre os veredictos judiciais. A secção seguinte descreve alguns dos estudos mais relevantes neste domínio, bem como os seus resultados e conclusões. 


\section{Estudos e conclusões: Que "Efeito CSI"?}

24 juries), isto é, uma amostra de indivíduos elegíveis para o serviço de jurados que avaliam um determinado caso e pronunciam um veredicto. Podlas (2006) levou a cabo um estudo onde procurou testar se os espectadores frequentes do CSI manifestavam maior exigência de provas para chegar a um veredicto de culpado. De um modo geral, Podlas procurou testar a validade da variante "acusação forte", segundo a qual existiria uma influência do CSI na exigência de provas científicas para obter um veredicto de culpa. De acordo com os resultados obtidos, não se verificaram diferenças entre os espectadores do CSI e os nãoespectadores. As suas conclusões apontaram para a inexistência de dados empíricos que suportem uma influência do CSI sobre uma maior exigência de prova científica para condenar, o que corresponderia a um elevar do padrão de dúvida razoável. Um interessante resultado lateral neste estudo foi a existência de um elevado número de veredictos de culpado apesar de a correcta decisão legal ser, à partida, a absolvição. Embora não seja conclusivo, a autora aponta para a possibilidade de, a haver influência do CSI, esta beneficiar a acusação (Podlas, 2006: 463).

Schweitzer e Saks (2007) levaram a cabo um estudo junto de estudantes universitários no qual foi empregue a transcrição de um julgamento para avaliar as suas percepções acerca do julgamento e das provas científicas apresentadas. Concluíram que apesar de não se verificarem grandes diferenças entre grupos de espectadores e não-espectadores, os espectadores de CSI mostraram-se mais cépticos perante as provas forenses quando estas eram inconclusivas ou pouco credíveis. Mais, os resultados obtidos poderão ainda ser entendidos como indicadores da manifestação de algo semelhante ao que foi atrás descrito como "efeito do produtor", na medida em que os espectadores de ficção televisiva do género CSI também se percepcionaram como mais bem preparados para avaliar provas científicas e alegaram possuir maior confiança nos seus veredictos (Schweitzer e Saks, 2007: 363). Tal também implica que os espectadores de CSI têm maiores expectativas que lhes sejam apresentadas provas científicas, manifestando-se mais críticos face a provas low tech (no caso apresentado tratava-se da análise de fibras capilares) do que os inquiridos que disseram não serem espectadores habituais de séries do género CSI (idem, ibidem).

O estudo de Donald Shelton et al. (2006) recorreu a uma amostra representativa de 1027 indivíduos, chamados a prestar serviço de jurado entre Junho e Agosto de 2006 em Washtenaw County, no estado do Michigan, EUA, aplicando um extenso inquérito por questionário que incluía questões acerca dos hábitos de consumo de média, expectativas acerca do tipo de provas apresentadas em tribunal e de que modo estas poderiam contribuir para um veredicto de culpado ou inocente. Os autores concluíram que ser espectador habitual do CSI ou séries do mesmo género não produz um efeito directo traduzido na absolvição de acusados culpados, nem se verificou causalidade entre ser espectador da série e revelar maior exigência de prova científica para a obtenção de um veredicto de culpa na maioria dos cenários criminais (Shelton et al., 2006: 367).

No entanto, embora não tenham sido encontradas relações de causalidade que indiquem a existência de um "Efeito CSI", os autores observaram que a larga maioria dos respondentes (independentemente de serem espectadores de CSI) manifestou expectativas de que a acusação apresentasse provas científicas em praticamente todos os 
tipos de casos criminais, particularmente quando as acusações são mais graves e outras provas existentes são meramente circunstanciais. Tal formação de expectativas, sendo independente da variável CSI, levou os autores a ponderar a existência do que designaram por tech effect, isto é, o aumento de expectativas e exigência de prova científica como reflexo dos avanços e progressos nas tecnologias e distribuição de informação (Shelton et al., 2006: 368).

Anos mais tarde, os mesmos autores (Kim et al., 2009) procuraram colmatar lacunas de estudos anteriores (Podlas, 2006; Shelton et al., 2006; Schweitzer e Saks, 2007), nomeadamente através do controlo de variáveis individuais através do uso de análises multivariadas e path analysis no estudo do processo de decisão dos jurados. Ainda que tenham sido reveladas diferenças associadas a características individuais (idade, género, etnia, nível de criminalidade na área de residência) nas decisões de condenação, ser consumidor de dramas televisivos como o CSI não produziu efeitos significativos e directos em situações que envolviam apenas provas circunstanciais ou testemunhas oculares. Na medida em que apenas se observou um "Efeito CSI" indirecto que se traduziu em maiores expectativas de provas científicas em casos que dependiam de prova circunstancial, os autores meramente reforçaram as conclusões anteriores e a necessidade de investigar outras dimensões do fenómeno.

Até ao momento, os estudos empíricos não confirmam a existência de um "Efeito CSI" na sua dimensão mais problemática, ou seja, de que os jurados, influenciados pelo imaginário do CSI, poderão promover ilibações erróneas devido à ausência ou irrelevância de prova científica. Mais ainda, uma análise promovida por Cole e Dioso-Villa (2009) relativamente às taxas de ilibação em julgamentos por júri em casos de crimes graves nos EUA, pese embora as limitações de um estudo deste género assinaladas pelos autores, não revelou alterações significativas nas taxas de ilibação no período pré e pós-CSI (Cole e Dioso-Villa, 2009: 1364).

Em suma, poderá dizer-se que a larga maioria das preocupação com o(s) "Efeito(s) CSI" redunda na questão do padrão de dúvida razoável $^{8}$ e nas expectativas e atitudes de cidadãos comuns chamados a tomar decisões em casos criminais. No sentido de avaliar os eventuais impactos da ficção televisiva sobre esses processos de decisão, foram efectuados os estudos acima citados, bem como análises mais focadas nos efeitos psicológicos do CSI sobre os critérios de dúvida razoável (Cutter, 2006; Mann, 2006; Tyler, 2006). Por outras palavras, os estudos em torno do "Efeito CSI" concernem particularmente aos sistemas de justiça criminal de tipo adversarial, nos quais as partes competem pelo triunfo de uma versão dos factos, frequentemente perante um júri composto por cidadãos comuns aos quais cabe a ponderação das evidências e argumentos trazidos perante o tribunal (Crombag, 2003). No entanto, será possível considerar a manifestação de eventuais efeitos noutros contextos legais. Com vista a este propósito, a secção que se segue promove uma reflexão acerca dos efeitos da série CSI no contexto português.

\section{Possíveis impactos no contexto português}

31 No contexto português, onde o julgamento por júri - embora consagrado no art. $13 .{ }^{\circ}$ do Código de Processo Penal - é muito pouco frequente, senão raro, a replicação de investigações acerca dos efeitos da série CSI junto de jurados será algo inviável. Todavia, podemos ponderar os potenciais impactos de séries do género CSI sobre o público, não enquanto eventuais manifestações de correlações entre uma série de televisão e as 
decisões de júris, mas argumentando em torno da hipótese avançada por Shelton e colegas relativa a um chamado tech effect que, tal como foi atrás descrito, será parte de "uma transformação mais alargada que ocorre na cultura popular e tecnológica" (Shelton et al., 2006: 333).

Ainda que não seja observável um efeito directo da série CSI, as conclusões dos estudos empíricos assinalam uma tendência para um aumento generalizado da exigência relativamente à produção de prova científica no âmbito da justiça criminal. Uma possível explicação é avançada por Tom Tyler (2006: 1079) e envolve o contributo de dois aspectos: por um lado, o declínio na confiança pública nas autoridades judiciais; por outro lado, o aumento da percepção de fidedignidade da prova científica.

Em países como Portugal é possível considerar os impactos do chamado "Efeito CSI" na perspectiva de outros públicos e actores que não os membros de um júri. Por exemplo, à imagem do estudo desenvolvido por Huey (2010) relativo à percepção dos agentes da polícia acerca das expectativas do público sobre o desempenho da investigação criminal. Conclui a autora que, na sua maioria, os agentes da polícia experienciam impactos nas suas interacções com o público, na medida em que se veem confrontados com expectativas exageradas relativamente às tecnologias usadas e mesmo sugestões acerca de como conduzir as investigações (Huey, 2010: 65).

Eventualmente, os tipos de efeitos mais plausíveis de ocorrer em jurisdições como a portuguesa serão de tipo cultural, influenciando as expectativas públicas de um modo mais amplo e difuso, podendo talvez confundir-se com o designado tech effect e mais ou menos relacionado com o "Efeito CSI". Helena Machado (2012), no âmbito de um estudo envolvendo reclusos em prisões portuguesas acerca das representações das tecnologias de DNA no combate ao crime, desenvolve uma tipologia composta por três tipos de efeitos: o efeito da "autoridade moral", o efeito da "distorção (credível) da realidade" e o efeito "educacional".

Segundo a autora, o efeito da "autoridade moral" decorre do protagonismo de tecnologias sofisticadas nas narrativas de combate ao crime disseminadas pelo CSI. Por associação, as forças policiais podem potencialmente beneficiar de um incremento de autoridade moral, do mesmo modo que a implementação e a expansão de tecnologias de vigilância e de combate ao crime podem ser favorecidas por maior apoio público. Neste sentido, há que perspectivar o incremento da pregnância de discursos securitários e punitivos, favoráveis ao aumento do controlo e restrição das liberdades civis, justificando a erosão de direitos com a necessidade de manter as populações desviantes sob apertado escrutínio (Cunha, 2008), ao mesmo tempo que a dureza das medidas é suavizada pela conceptualização da ciência e da tecnologia como neutra e geralmente benéfica para a sociedade.

A "distorção (credível) da realidade" corresponde àquilo que é referido por Huey (2010) e Patry et al. (2008), isto é, apesar de os métodos e técnicas científicos serem compatíveis com procedimentos existentes no mundo real, a sua acessibilidade, exequibilidade e fidedignidade como é representada no género CSI é assinalada como sendo largamente exagerada e distorcida. Tal é passível de gerar concepções distorcidas acerca da investigação criminal no mundo real junto de públicos que aguardam resoluções rápidas e eficientes para casos criminais, consistentes com o imaginário do CSI, mas que elidem os obstáculos e contingências do mundo real, tais como a falta de recursos humanos e materiais (Costa, 2003), restrições legais e burocráticas, ou a inexistência de certas bases de dados capazes de fornecer pistas em poucos segundos. 

académicos, quer também para decisores políticos, actores do sistema de justiça criminal e o público em geral, ainda que possa ser entendido como mero efeito mediático resultante da popularidade de uma série de televisão. Apesar de uma porção considerável da investigação empírica em torno do "Efeito CSI" dizer respeito a preocupações relacionadas com os impactos nas crenças e processos de tomada de decisão por parte de jurados no contexto de sistemas de justiça de tipo adversarial (Cole e Dioso-Villa, 2009; Shelton et al., 2006; Kim et al., 2009; Podlas, 2006; Schweitzer e Saks, 2007), outras obras tendem a abordar as dimensões culturais e a difusão de significados acerca da ciência, da tecnologia e do trabalho da polícia (vejam-se, por exemplo, Ley et al., 2010; Cavender e Deutsch, 2007; Gever, 2005; Kruse, 2010; Mopas, 2007). 
42 Não tendo sido encontradas correlações significativas entre o visionamento da série e alterações nas decisões de jurados, e na medida em que a demanda por conclusões empiricamente fundadas no que respeita ao funcionamento de júris parece destinada à inconclusividade (Kim et al., 2009), tendemos a considerar o "Efeito CSI" como uma metáfora. Não se pretende excluir a eventual possibilidade de a série produzir algum tipo de efeito concreto. No entanto, optamos aqui por lançar uma conceptualização hipotética que toma a série de televisão e os seus potenciais efeitos no âmbito de transformações societais mais alargadas.

43 A infusão de um imaginário ficcional que retrata de modo idealizado como uma investigação criminal pode ser rápida, objectiva e produzir sempre resultados poderá ser passível de gerar algumas expectativas de transformações concretas no mundo real. Em Portugal, as relações dos cidadãos com a justiça tendem a ser algo distantes e pouco harmoniosas (Barreto, 2000). Segundo um estudo em larga escala, para além de uma baixa propensão para o recurso aos tribunais para a resolução de litígios, predominam percepções e avaliações negativas em relação aos tribunais (Santos et al., 1996: 88).

44 O declínio da confiança pública na justiça parece acompanhar a tendência das últimas décadas do século XX nas sociedades ocidentais, de uma aparente "crise da democracia" (Miguel, 2008: 252). Entre diversas hipóteses de explicação, as mais robustas surgem associadas às transformações do papel dos média nas sociedades. A hipótese da "espiral do cinismo" coloca os média, o público e as instituições como elementos de uma espiral que se realimenta continuamente, construindo imagens públicas de descrédito generalizado, actuando os média como pivot do processo (Miguel, 2008: 255; Pina, 2009: 83).

O papel dos média tem sido fulcral, nomeadamente ao promover a cobertura extensiva de alguns casos criminais (por exemplo, os casos Joana e Madeleine McCann) que acabam por perdurar na memória colectiva como símbolos das limitações da investigação criminal no mundo real. Tal é particularmente marcante quando os média mais sensacionalistas tendem a promover enquadramentos narrativos alinhados com o imaginário ficcional propalado pelo CSI (Machado e Santos, 2011), em que a ciência se apresenta como a derradeira solução para os crimes. Não será, pois, surpreendente, que a associação entre a ciência e a justiça surja cada vez mais como instrumento retórico no discurso político (Machado e Silva, 2008: 156).

Deste modo, propomos um possível entendimento do chamado "Efeito CSI" como uma metáfora que assinala o que Shelton et al. (2006) designaram como tech effect e que concentra na vaga descrição de "Efeito CSI" toda uma gama de transformações decorrentes não só dos avanços na ciência e na tecnologia, mas também da conjugação entre o declínio da confiança dos cidadãos no Estado e no sistema de justiça e a reemergência de uma espécie de ideologia positivista assente nas imagens de objectividade, neutralidade e certeza associadas ao conhecimento científico (Jasanoff, 2006).

47 A impregnação dos discursos sobre a justiça e sobre o combate ao crime com apelos ao imperativo tecnológico e as associações com o imaginário de séries como o CSI podem estar na base do desenvolvimento de narrativas que remetem para a renovação de uma mitologia (re)fundadora dos princípios e pressupostos da justiça e dos seus actores. Por outras palavras, poderíamos falar da transição de uma ideia de justiça feita por seres humanos para uma justiça "tecnológica" assente em promessas de maior rapidez, 
eficiência e absoluta neutralidade, onde os discursos dissonantes e vozes críticas são ofuscados pela retórica da eficácia e fiabilidade de novas técnicas como a genética forense (Machado et al., 2010: 544).

Em suma, os impactos do "Efeito CSI" em Portugal podem surgir mais como uma "metáfora" da submissão simbólica (talvez cada vez menos simbólica e mais concreta?) do direito à ciência (Santos, 2000), em função da evocação cada vez mais enfática nos discursos públicos, políticos e mediáticos do papel central da ciência e da tecnologia na justiça e no combate à criminalidade.

\section{BIBLIOGRAFIA}

ALTHEIDE, David L. (1992), “Gonzo justice”, Symbolic Interaction, 15 (1), 69-86.

BARRETO, António (org.) (2000), Justiça em Crise? Crises da justiça, Lisboa, Publicações Dom Quixote. BREWER, Paul R. \& LEY, Barbara (2009), "Media use and public perceptions of DNA evidence", Science Communication, 32 (1), 93-117.

CAVENDER, Gray \& DEUTSCH, Sarah K. (2007), “CSI and moral authority: The police and science”, Crime, Media, Culture, 3 (1), 67-81.

COLE, Simon A. \& DIOSO-VILLA, Rachel (2007), "CSI and its effects: Media, juries, and the burden of proof", New England Law Review, 41 (3), 435-470.

COLE, Simon A. \& DIOSO-VILLA, Rachel (2009), "Investigating the 'CSI effect' effect: Media and litigation crisis in criminal law”, Stanford Law Review, 61 (6), 1335-1374.

COSTA, Susana (2003), A Justiça em Laboratório - A identificação por perfis genéticos de ADN: Entre a harmonização transnacional e a apropriação local, Coimbra, Almedina.

CROMBAG, Hans (2003), “Adversarial or inquisitorial. Do we have a choice?”, in Peter Koppen \& Steven Penrod (eds.), Adversarial versus Inquisitorial Justice: Psychological perspectives on criminal justice, New York, Kluwer Academic/Plenum Publishers, 21-25.

CUNHA, Manuela Ivone (2008), "Disciplina, controlo, segurança: No rasto contemporâneo de Foucault”, in Catarina Fróis (org.), A Sociedade Vigilante: Ensaios sobre privacidade, identificação e vigilância, Lisboa, Imprensa de Ciências Sociais, 67-81.

CUTTER, Anthony M. (2006), “To clear or to convict? The role of genomics in criminal justice”, Genomics, Society and Policy, 2 (1), 1-15.

DEUTSCH, Sarah K. \& CAVENDER, Gray (2008), “CSI and forensic realism”, Journal of Criminal Justice and Popular Culture, 15 (1), 34-53.

GERBNER, George \& GROSS, Larry (1976), "Living with television: The violence profile”, Journal of Communication, 26 (2), 173-199.

GEVER, Martha (2005), "The spectacle of crime, digitized. CSI: Crime scene investigation and social anatomy", European Journal of Cultural Studies, 8 (4), 445-463. 
GUIBENTIF, Pierre; GORJÃO, Vanda \& CHETA, Rita (2002), Comunicação Social e Representações do Crime, Lisboa, Centro de Estudos Judiciários, Gabinete de Estudos Jurídico-Sociais.

HANS, Valerie P. \& DEE, Juliet L. (1991), "Media coverage of law: Its impact on juries and the public”, American Behavioral Scientist, 35 (2), 136-149.

HUEY, Laura (2010), “'I've seen this on CSI”: Criminal investigators' perceptions about the management of public expectations in the field", Crime, Media, Culture, 6 (1), 49-68.

JASANOFF, Sheila (2005), “Law's knowledge: Science for justice in legal settings", American Journal of Public Health, 95, 49-58.

JASANOFF, Sheila (2006), "Just evidence: The limits of science in the legal process", Journal of Law, Medicine \& Ethics, 34 (2), 328-341.

KIM, Young S.; BARAK, Gregg \& SHELTON, Donald E. (2009), "Examining the 'CSI-effect' in the cases of circumstantial evidence and eyewitness testimony: Multivariate and path analyses", Journal of Criminal Justice, 37 (5), 452-460.

KRUSE, Corinna (2010), "Producing absolute truth: CSI science as wishful thinking”, American Anthropologist, 112 (1), 79-91.

LEY, Barbara; JANKOWSKI, Natalie \& BREWER, Paul (2010), "Investigating CSI: Portrayals of DNA testing on a forensic crime show and their potential effects", Public Understanding of Science, Online first, 27 Maio 2010, 1-17.

MACHADO, Helena (2012), "Prisoners' views of CSI's portrayal of forensic identification technologies: A grounded assessment", New Genetics and Society (no prelo).

MACHADO, Helena \& SANTOS, Filipe (2011), "Popular press and forensic genetics in Portugal: Expectations and disappointments regarding two cases of missing children", Public Understanding of Science, 20 (3), 303-318.

MACHADO, Helena \& SILVA, Susana (2008), “Confiança, voluntariedade e supressão dos riscos: Expectativas, incertezas e governação das aplicações forenses”, in Catarina Fróis (ed.), A Sociedade Vigilante: Ensaios sobre vigilância, privacidade e anonimato, Lisboa: Imprensa de Ciências Sociais, 151-174.

MACHADO, Helena; SILVA, Susana \& AMORIM, António (2010), "Políticas de identidade: Perfil de DNA e a identidade genético-criminal”, Análise Social, XLV (196), 537-553.

MACHADO, Helena; SILVA, Susana \& SANTOS, Filipe (2008), Justiça Tecnológica: Promessas e desafios, Ermesinde, Ecopy.

MANN, Michael D. (2006), “The 'CSI effect': Better jurors through television and science?”, Buffalo Public Interest Law Journal, XXIV, 157-183.

MIGUEL, Luis Felipe (2008), “A mídia e o declínio da confiança na política”, Sociologias, 10 (9), 250-273.

MOPAS, Michael (2007), “Examining the 'CSI effect' through an ANT lens”, Crime, Media, Culture, 3 (1), 110-117.

PATRY, Marc W. et al. (2008), "Blurring the line between fact and fiction: Expert opinions about forensic investigation tools represented on CSI", Proceedings of the North American Correctional \& Criminal Justice Psychology Conference, 2008, 94-97.

PINA, Sara (2009), Media e Leis Penais, Porto, Almedina. 
PODLAS, Kimberlianne (2006), “The 'CSI Effect': Exposing the media myth”, Fordham Intellectual Property, Media and Entertainment Law Journal, 16, 429-465.

PRAINSACK, Barbara \& TOOM, Victor (2010), “The Prüm regime. Situated dis/empowerment in transnational DNA profile exchange”, British Journal of Criminology, 50, 1117-1135.

PRATT, Travis et al. (2006), “'This isn't CSI': Estimating the national backlog of forensic DNA cases and the barriers associated with case processing”, Criminal Justice Policy Review, 17 (1), 32-47.

ROBBERS, Monica (2008), "Blinded by science: The social construction of reality in forensic television shows and its effect on criminal jury trials", Criminal Justice Policy Review, 19 (1), 84-102.

ROSKO-EWOLDSEN, David et al. (2009), "Media priming: An updated synthesis”, in Jennings Bryant \& Mary Beth Oliver (eds.), Media Effects: Advances in theory and research, New York, Taylor \& Francis, 74-93.

REINER, Robert (2002), "Media made criminality: The representation of crime in the mass media", in Robert Reiner, Mike Maguire \& Rod Morgan (orgs.), The Oxford Handbook of Criminology, Oxford, Oxford University Press, 376-416.

SACCO, Vincent (1995), "Media constructions of crime", Annals of the American Academy of Political and Social Science, 539, 141-154.

SANTOS, Boaventura de Sousa (2000), A Crítica da Razão Indolente: Contra o desperdício da experiência, Porto, Afrontamento.

SANTOS, Boaventura de Sousa (2005), "Os tribunais e as novas tecnologias de comunicação e de informação", Sociologias, 13 (7), 82-109.

SANTOS, Boaventura de Sousa et al. (1996), Os Tribunais nas Sociedades Contemporâneas. $O$ caso português, Porto, Afrontamento.

SCHWEITZER, Nicholas J. \& SAKS, Michael J. (2007), “The CSI effect: Popular fiction about forensic science affects the public's expectations about real forensic science", Jurimetrics, 47 , 357-364.

SHELTON, Donald E.; KIM, Young S. \& BARAK, Gregg (2006), “A study of juror expectations and demands concerning scientific evidence: Does the 'CSI Effect' exist?", Vanderbilt Journal of Entertainment and Technology Law, 9 (2), 331-368.

THOMAS, William \& THOMAS, Dorothy (1928), The Child in America: Behavior problems and programs, New York, Alfred Knopf.

TYLER, Tom R. (2006), "Viewing CSI and the threshold of guilt: Managing truth and justice in reality and fiction”, The Yale Law Journal, 115 (5), 1050-1085.

WILLING, Richard (2004), “'CSI effect' has juries wanting more evidence”, USA Today, 8 Maio, disponível em: <http://www.usatoday.com/news/nation/2004-08-05-csi-effect_x.htm> [consultado em: 15 de Setembro de 2011].

ZALMAN, Marvin (2008), “The adversary system and wrongful conviction”, in C. Ronald Huff \& Martin Killias (eds.), Wrongful Conviction. Internati justice, Philadelphia, Temple University Press, 71-92 . 


\section{NOTAS}

1. Ao longo deste artigo, usaremos o termo CSI para designar não só a série televisiva Crime Scene Investigation, mas também, de um modo geral, todo o género televisivo de ficção criminal com referência à temática forense.

2. A série estreou na SIC em Julho de 2004, alcançando uma audiência média de 5,2\% e um share de 30,7\% (MARKTEST (2004), “SIC estreia segunda série de CSI”. Disponível em: http://www. marktest.com/wap/a/n/id 665.aspx [consultado em: 6 de Janeiro de 2012]). Segundo o site do jornal Meios \& Publicidade, citando dados de 2006, o canal AXN conseguiu colocar CSI como o programa mais visto na televisão por cabo. (Disponível em: http:// www.meiosepublicidade.pt/2007/01/26/TVI_dominou_audi_ncias_e_publici/ [consultado em: 6 de Janeiro de 2012].)

3. No contexto da psicologia cognitiva aplicada aos média, priming designa o efeito de exposição prévia a mensagens, conceitos e imagens que afectam comportamentos e decisões subsequentes (Roskos-Ewoldsen et al., 1994: 74).

4. Veja-se, por exemplo, um artigo no tablóide USA Today (Willing, 2004) acerca do "Efeito CSI", disponível em: http://www.usatoday.com/news/nation/2004-08-05-csi-effect_x.htm [consultado em: 15 de Setembro de 2011].

5. "Se as situações são definidas como reais, elas são reais nas suas consequências" (Thomas e Thomas 1928: 572, tradução do autor).

6. 0 voir dire é uma formalidade característica dos sistemas de Common Law que se refere a uma fase processual em que as partes e o juiz discutem a admissibilidade de prova e a competência das testemunhas e dos membros do júri.

7. Aparentemente, devido à popularidade da série CSI, aumentou em Portugal a procura de vagas em cursos de medicina forense: "Série televisiva 'CSI' faz aumentar inscrições nos cursos", disponível em: http://ww1.rtp.pt/noticias/index.php?article=275038\&visual=26 [consultado em: 15 de Dezembro de 2011].

8. Segundo Jasanoff (2005), no contexto legal dos Estados Unidos da América, o padrão de dúvida razoável pode variar consoante as circunstâncias (civil, criminal). Geralmente, considera-se que a "prova para além da dúvida razoável" é exigida sempre que a vida ou liberdade de um indivíduo é posta em causa.

\section{RESUMOS}

A série de televisão CSI - Crime Scene Investigation serviu para designar um fenómeno construído pelos média norte-americanos segundo o qual a ficção televisiva sobre a temática da ciência forense tem vindo a produzir impactos sobre o sistema de justiça criminal. Contudo, estudos e debates académicos em torno do chamado "Efeito CSI" não lograram, até ao momento, obter evidências significativas de que a série de televisão esteja a alterar o modo como cidadãos chamados a prestar serviço de júri avaliam provas científicas ou a ausência destas. Este artigo revê a literatura científica acerca do fenómeno, abordando as várias dimensões e possíveis significados do "Efeito CSI" e reflectindo sobre potenciais impactos no contexto português. 
The television series CSI - Crime Scene Investigation has been used to name a phenomenon constructed by the north-american media, according to which television fiction on the subject of forensic science has come to generate impacts on the criminal justice system. However, academic studies and debates surrounding the so-called "CSI Effect" have not been able so far to find significant evidence that the television series is changing the way citizens called to jury service evaluate scientific evidence, or its absence. This article reviews the scientific literature about the phenomenon, addressing the various dimensions and possible meanings of the "CSI Effect", while reflecting on potential impacts in the Portuguese context.

La série télévisée CSI - Crime Scene Investigation (Les Experts) servit à désigner un phénomène construit par l'médias nord-américaine, selon qui la fiction de télévision sur le thème de la science médico-légale est venu d'avoir un impact sur le système de justice pénale. Cependant, des études et des débats académiques autour de le soi-disant Effet CSI ont manqué jusqu'ici à obtenir des preuves significatives que la série télévisée change la façon dont les citoyens appelés à des fonctions de juré évaluer les preuves scientifiques, ou leur absence. Cet article examine la littérature scientifique sur le phénomène, en accentuant les différentes dimensions et significations possibles de l'Effet CSI et reflétant sur les impacts potentiels sur le contexte portugais.

\section{ÍNDICE}

Palavras-chave: efeito CSI, justiça, ciência forense

Keywords: CSI Effect, justice, forensic science

Mots-clés: effet CSI, justice, science médicolégale

\section{AUTOR}

\section{FILIPE SANTOS}

Doutorando em Sociologia, Centro de Investigação em Ciências Sociais da Universidade do Minho (CICS-UM), filipesantos@ics.uminho.pt. 